\title{
Sustainable environmental chemistry and technology with focus on the Mediterranean area
}

\author{
loannis A. Katsoyiannis ${ }^{1} \cdot$ Dimitra Voutsa $^{1}$
}

Received: 6 February 2018 / Accepted: 16 February 2018 / Published online: 7 March 2018

(C) Springer-Verlag GmbH Germany, part of Springer Nature 2018

This special issue intends to give a brief overview of current scientific topics for sustainable environmental chemistry and technology. This issue includes eight articles accepted for publication after the normal peer review process. These articles were presented at the 22nd Panhellenic Chemistry Conference held in Thessaloniki, Greece, 1-4 December 2016. The conference was organized by the Association of Greek Chemists under the auspices of the Department of Chemistry of Aristotle University of Thessaloniki.

The published articles cover scientific areas of environmental chemistry and environmental technology. The articles present the occurrence, temporal variation, and distribution of polar organic compounds in $\mathrm{PM}_{10}$ and $\mathrm{PM}_{2.5}$ in the coastal urban area of Thessaloniki City (Balla et al. 2017), the levels and chemical characterization of $\mathrm{PM}_{10}$ and their possible sources in the surrounding of lignite mine area (Samara et al. 2017), the occurrence and variation of natural radionuclides and minor and trace elements in water and lake sediments of a lignite mine area (Noli and Tsamos 2017), and the occurrence of various elements in deposited dust and human hair (Eqani et al. 2017). In the field of environmental technology, the articles present the effects of ozonation treatment on the organic matter (Stylianou et al. 2017a), the use of novel adsorbents for removal of heavy metals (Kokkinos et al. 2017), the use of reductive precipitation and membrane separation for chromate removal from groundwaters (Stylianou et al. 2017b), and the treatment of landfill leachate by membrane bioreactors (Gkotsis et al. 2017).

In summary, this issue attempts to present various environmental issues regarding the presence and possible sources of

Responsible editor: Philippe Garrigues

Ioannis A. Katsoyiannis

katsogia@chem.auth.gr

1 Department of Chemistry, Aristotle University of Thessaloniki, Thessaloniki, Greece organic pollutants, toxic elements, ionic constituents, and radionuclides in atmosphere and aquatic environment, as well as technological approaches for treatment of water and wastewater. We hope that these articles offer important insight in environmental problems and besides the scientific interest; they can also promote awareness to authorities regarding the intensification of research and possible solutions to these problems.

This special issue was edited by the Assistant Professor, Dr. Ioannis A. Katsoyiannis, and the Full Professor, Dr. Dimitra Voutsa, both from the Department of Chemistry of Aristotle University of Thessaloniki.

\section{References}

Balla D, Voutsa D, Samara C (2017) Study of polar organic compounds in airborne particulate matter of a coastal urban city. Environ Sci Pollut Res. https://doi.org/10.1007/s11356-017-9993-2

Eqani SAMAS, Tanveer ZI, Qiaoqiao C, Cincinelli A, Saqib Z, Mulla SI, Ali N, Katsoyiannis IA, Shafqat MN, Shen H (2017) Occurrence of selected elements (Ti, Sr, Ba, V, Ga, Sn, Tl, and Sb) in deposited dust and human hair samples: implications for human health in Pakistan. Environ Sci Pollut Res. https://doi.org/10.1007/s11356-017-0346-y

Gkotsis P, Tsilogeorgis J, Zouboulis A (2017) Hydraulic performance and fouling characteristics of a membrane sequencing batch reactor (MSBR) for landfill leachate treatment under various operating conditions. Environ Sci Pollut Res. https://doi.org/10.1007/s11356-0170142-8

Kokkinos E, Soukakos K, Kostoglou M, Mitrakas M (2017) Cadmium, mercury, and nickel adsorption by tetravalent manganese feroxyhyte: selectivity, kinetic modeling, and thermodynamic study. Environ Sci Pollut Res. https://doi.org/10.1007/s11356-017-9738-2

Noli F, Tsamos P (2017) Seasonal variations of natural radionuclides, minor and trace elements in lake sediments and water in a lignite mining area of North-Western Greece. Environ Sci Pollut Res. https://doi.org/10.1007/s11356-017-9801-z

Samara C, Argyropoulos G, Grigoratos T, Kouras A, Manoli E, Andreadou S, Pavloudakis F, Sahanidis C (2017) Chemical characterization and receptor modeling of $\mathrm{PM}_{10}$ in the surroundings of the opencast lignite mines of Western Macedonia, Greece. Environ Sci Pollut Res. https://doi.org/10.1007/s11356-017-9655-4

Stylianou SK, Katsoyiannis IA, Ernst M, Zouboulis AI (2017a) Impact of $\mathrm{O}_{3}$ or $\mathrm{O}_{3} / \mathrm{H}_{2} \mathrm{O}_{2}$ treatment via a membrane contacting system on the 
composition and characteristics of the natural organic matter of surface waters. Environ Sci Pollut Res. https://doi.org/10.1007/s11356017-9554-8

Stylianou S, Simeonidis K, Mitrakas M, Zouboulis A, Ernst M, Katsoyiannis IA (2017b) Reductive precipitation and removal of $\mathrm{Cr}(\mathrm{VI})$ from groundwaters by pipe flocculation-microfiltration. Environ Sci Pollut Res. https://doi.org/10.1007/s11356-017-9967-4

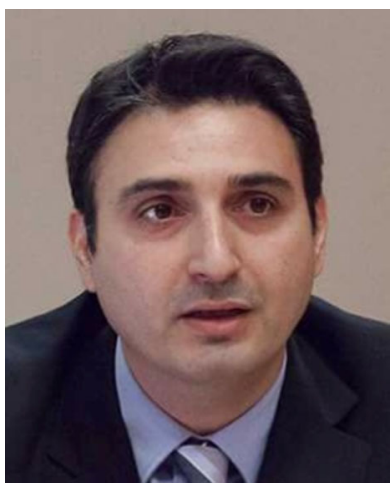

Prof. Katsoyiannis has received his PhD from Aristotle University of Thessaloniki in 2003, and following, he conducted a post-doctoral research firstly at the Technical University of Berlin as an Alexander von Humboldt research fellow and later at the Swiss Federal Institute of Aquatic Science and Technology (Eawag) as a recipient of a Marie Curie Individual Fellowship. Afterwards, he worked for 4 years as an environmental chemical engineer in the industrial sector of power plant construction, firstly for Alstom Power in Baden, $\mathrm{CH}$, and then for Hitachi Power Europe in Hamburg, DE. In 2014, he was an appointed lecturer at the laboratory of Chemical and Environmental Technology of the Department of Chemistry of Aristotle University of Thessaloniki, and since, 2016 he is an assistant professor at the same department. His research interests are the investigation of the removal of inorganic and organic contaminants from groundwaters, the analysis of the role of sorption and oxidation in contaminant removal, wastewater treatment, and reuse, and membrane development for drinking water treatment. He is the delegate of Greek Chemical Society at the Division of Chemistry and Environment of the EuCheMS.

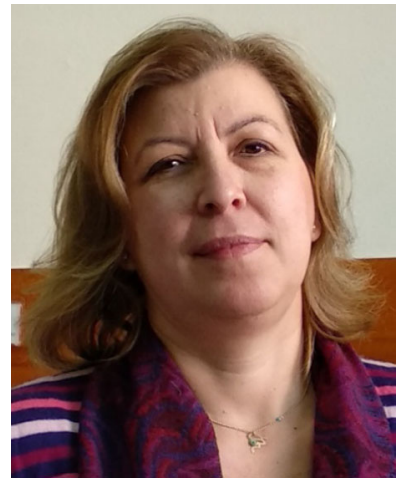

Dr. Dimitra Voutsa is a full professor of Environmental Chemistry at the Chemistry Department of Aristotle University, Thessaloniki, Greece. She is currently a director of Environmental Pollution Control Laboratory. Her research activities include as follows: (a) drinking water quality, water treatment, and regulated and emerging disinfection by-products; (b) occurrence, fate, and effects of organic pollutants in aquatic environment, atmosphere, and technical systems; and (c) chemical characterization of airborne atmospheric particles. She has published over 80 articles in international peer-reviewed scientific journals and chapters in books with over 3500 citations. She has supervised many $\mathrm{PhD}$ and MSc theses. She has participated in many scientific committees aiming at the critical evaluation of various environmental issues. She is a member of the advisory board in the journal Environmental Science Europe. She is a member of Environmental Council of Aristotle University. 